\title{
Perceived Usefulness of Business Coaching on the Relationship between Entrepreneurial Competencies and Business Success
}

\author{
Mohd Mahfudz bin IDRIS ${ }^{1}$, Saridan bin ABU BAKAR ${ }^{2}$
}

Received: July 25, 2020 Revised: August 23, 2020 Accepted: September 03, 2020

\begin{abstract}
The present study aims to investigate the perceived usefulness of business coaching as a moderator between the association of entrepreneurial competencies and business success of women micro-entrepreneurs. This study employs a stratified random sampling technique to collect data from women micro-entrepreneurs who attended business coaching sessions. In total, 261 questionnaires were distributed and collected. This study has divided the moderator (i.e., perceived usefulness of business coaching) into two groups, namely, group 1 (with a low mean) and group 2 (with a high mean) for moderation analysis. By using a comparative analysis of the path coefficient for groups 1 and 2 , the path is moderated by the perceived usefulness of business coaching if the beta value for group 1 is significant, and the beta value for group 2 is non-significant. The results show that eight out of a total of sixteen hypotheses were supported, while the remaining hypotheses were rejected. The findings of the study suggest that the domains of entrepreneurial competencies for women micro-entrepreneurs, including strategic, commitment, conceptual, opportunity, and relationship competencies, together with the perceived usefulness of business coaching, are vital for the business success and should remain the principal focus of future research in women entrepreneurship.
\end{abstract}

Keywords: Entrepreneurial Competencies, Perceived Usefulness of Business Coaching, Women Micro-Entrepreneurs

JEL Classification Code: C3, M1, Y4

\section{Introduction}

The role of women in society is changing in several ways, they are involved in new kinds of activities, including entrepreneurship, which contribute to the socio-economic development (Satpayeva et al., 2020). The traditional role of women as full-time housewives has changed dramatically with their increasing participation in economic activities (Mustapa et al., 2018).

Entrepreneurship can be considered a new challenge, an adventurous experience, and an opportunity to determine the future by creating a business model that acts as a stimulant

${ }^{1}$ First Author and Corresponding Author. DBA Candidate, Arshad Ayub Graduate Business School, Universiti Teknologi MARA (UITM), Malaysia [Postal Address: 40450 Shah Alam, Selangor, Malaysia] Email: mahfudzidris@gmail.com

${ }^{2}$ Associate Professor, Arshad Ayub Graduate Business School, Universiti Teknologi MARA (UITM), Selangor, Malaysia.

Email: drsaridan@gmail.com

(c) Copyright: The Author(s)

This is an Open Access article distributed under the terms of the Creative Commons Attribution Non-Commercial License (https://creativecommons.org/licenses/by-nc/4.0/) which permits unrestricted non-commercial use, distribution, and reproduction in any medium, provided the original work is properly cited. for national competitiveness. The competent entrepreneur is needed to achieve business success. Entrepreneurs are not simply born with an innate competence, but can cultivate it within their sociocultural context (Lee \& Kim, 2019). About $88 \%$ of the entire Malaysian women entrepreneurs are categorized as women micro-entrepreneurs (Al Mamun et al., 2016). These data showed that women micro-entrepreneurs contribute significantly to the national economy.

Women micro-entrepreneurs are women who establish, manage, and operate a particular micro-enterprise. The entrepreneurial competencies are critical to business success with academic and practical appeals (Ahmad et al., 2010) and vital for women micro-entrepreneurs (Zainol et al., 2017). The lack of entrepreneurial competencies may further complicate the journey towards business success among women micro-entrepreneurs. Therefore, women micro-entrepreneurs must be given particular attention in improving their relevant competencies to succeed in their businesses. Mitchelmore and Rowley (2010) recommended for research on entrepreneurial competencies to concentrate on the entrepreneur's features and characteristics, such as the knowledge and skills that enable an entrepreneur to run a business competently. 
Business coaching is a collaborative relationship between coaches and clients, within which coaches bring business experience and focus primarily on business success (Dobrea \& Maiorescu, 2015). As articulated by Ellinger et al. (2003), business coaching has a positive perceived value, particularly important to improve poor performance and to link individual competencies with business success.

Perceived usefulness influences the attitude towards the method used and the behavioral intention to use the technique (Bradley, 2009). Hence, to achieve success in business, women micro-entrepreneurs must be coached with the right knowledge and guidance on the required skills and attitudes. Also, they must realize, acknowledge and appreciate the value of business coaching.

Therefore, this study seeks to examine the moderating role of perceived usefulness of business coaching and their causal links among domains of entrepreneurial competencies and business success. The inclusion of these variables will allow for an exploration of the extent to which the internal factors, entrepreneurial competencies, and the external factors; perceived usefulness of business coaching interact to influence the business success among the women microentrepreneurs.

\section{Literature Review}

\subsection{Direct Effect of Entrepreneurial Competencies on Business Success}

Previous studies have recognized that business success is heavily determined by the entrepreneurial competencies of entrepreneurs (Tehseen \& Ramayah, 2015; Ng \& Kee, 2013). Ahmad et al. (2010) stated that the acceptance of business success through the lens of entrepreneurial skills is commentating. It provides business people with useful knowledge about the method they should use in running their business and influences them to be aware of the impending positive or negative impacts of their practice. Lazer and Paul (2015) defined entrepreneurial competencies as the underlying characteristics possessed by individuals, which assist them in executing the tasks in a most befitting manner. Man and Lau (2000) affirmed that the entrepreneurial competencies act as a bridge between the characteristics at the individual level and business success at the firm level.

Women micro-entrepreneurs are required to have the necessary entrepreneurial competencies to act as a catalyst for business success. They have to perform various complex tasks, given their engagement in various functional, managerial, and entrepreneurial duties. These functions are multitudinous and can be optimally achieved via the right mix of competencies (Mole et al., 1993).

Entrepreneurial competencies comprise those skills that are deeply rooted in a person's background as well as skills that can be acquired and learned at work (Man \& Lau, 2005). According to Mitchelmore and Rowley (2013), one of the objectives to develop classifications of entrepreneurial competencies is to be able to measure such skills. It had been recognized as a specific group of skills that are relevant to business success among women entrepreneurs. Ahmad et al. (2010) have found eight competency domains, namely, strategic, commitment, conceptual, opportunity, organizing and leading, relationship, personal, and technical competencies, which are the most relevant and context-specific domains of entrepreneurs' entrepreneurial competencies.

Hence, this study examined every domain of the entrepreneurial competencies to investigate whether each of the competencies would be directly affecting the women micro-entrepreneurs' business success. The investigation is based on the following hypotheses:

H1: Strategic competency is significantly and positively related to business success among women microentrepreneurs.

H2: Commitment competency is significantly and positively related to business success among women microentrepreneurs.

H3: Conceptual competency is significantly and positively related to business success among women microentrepreneurs.

H4: Opportunity competency is significantly and positively related to business success among women microentrepreneurs.

H5: Organizing and leading competency are significantly and positively related to business success among women micro-entrepreneurs.

H6: Relationship competency is significantly and positively related to business success among women microentrepreneurs.

H7: Personal competency is significantly and positively related to business success among women microentrepreneurs.

H8: Technical competency is significantly and positively related to business success among women microentrepreneurs.

\subsection{The Moderating Effects of Perceived Usefulness of Business Coaching}

Omar et al. (2014) conducted a study on the low-income women micro-entrepreneurs and recommended them to be given business coaching to increase their chances of success in business. Business coaching is critical to learn new facts and accomplish new tasks (Onyemah, 2009). It has an enormous impact on the development of entrepreneurs' confidence, which is an incentive or driver to enhance business success (Dobrea \& Maiorescu, 2015). 
Furthermore, Walker-Fraser (2011) emphasized that business coaching provides essential outcomes or high values to those who receive it. Jung and Berthon (2009) commented that the use of business coaching is driven by the individual's attitude as dictated by its perceived usefulness. Hence, besides being coached with the right knowledge, guided on the required skills and attitudes to succeed in business, women micro-entrepreneurs must realize the value of business coaching.

Therefore, the following hypotheses about the moderating effects of perceived usefulness of business coaching on the relationships among domains of entrepreneurial competencies and business success, are developed:

H9: Perceived usefulness of business coaching moderates the relationship between strategic competency and women micro-entrepreneurs' business success. Specifically, the relationship will be stronger when perceived usefulness of business coaching is higher than another business coaching with lower perceived usefulness.

H10: Perceived usefulness of business coaching moderates the relationship between commitment competency and women micro-entrepreneurs' business success. Specifically, the relationship will be stronger when perceived usefulness of business coaching is higher than another business coaching with lower perceived usefulness.

H11: Perceived usefulness of business coaching moderates the relationship between conceptual competency and women micro-entrepreneurs' business success. Specifically, the relationship will be stronger when perceived usefulness of business coaching is higher than another business coaching with lower perceived usefulness.

H12: Perceived usefulness of business coaching moderates the relationship between opportunity competency and women micro-entrepreneurs' business success. Specifically, the relationship will be stronger when perceived usefulness of business coaching is higher than another business coaching with lower perceived usefulness.

H13: Perceived usefulness of business coaching moderates the relationship between organizing and leading competency and women micro-entrepreneurs' business success. Specifically, the relationship will be stronger when perceived usefulness of business coaching is higher than another business coaching with lower perceived usefulness.

H14: Perceived usefulness of business coaching moderates the relationship between relationship competency and women micro-entrepreneurs' business success. Specifically, the relationship will be stronger when perceived usefulness of business coaching is higher than another business coaching with lower perceived usefulness.

H15: Perceived usefulness of business coaching moderates the relationship between personal competency and women micro-entrepreneurs' business success. Specifically, the relationship will be stronger when perceived usefulness of business coaching is higher than another business coaching with lower perceived usefulness.

H16: Perceived usefulness of business coaching moderates the relationship between technical competency and women micro-entrepreneurs' business success. Specifically, the relationship will be stronger when perceived usefulness of business coaching is higher than another business coaching with lower perceived usefulness.

\section{Theoretical Framework}

The significant constructs that form the theoretical framework for this study include every domain of entrepreneurial competencies, perceived usefulness of business coaching, and business success. The theoretical framework developed for this study is depicted in Figure 1.

\section{Methodology}

This study is a correlational field study and employed a quantitative research method. The unit of analysis for this study is individual. Stratified random sampling has been used in this study to determine the sampling technique. Once the population had been stratified, a sample of women micro-entrepreneurs was selected proportionately to the number of women micro-entrepreneurs in the stratum. This study employed a simple random sampling technique to select the sample so that the same opportunity could be given to each sample frame (Othman \& Ishak, 2009). Data were collected using a self-administered questionnaire. This study managed to secure 261 completed questionnaires from selected respondents. The data obtained was analyzed using the Structural Equation Modeling (SEM).

\section{Data Analysis and Results}

\subsection{Individual Confirmatory Factor Analysis (CFA) and Reliability}

Before testing the measurement model, individual Confirmatory Factor Analyses (CFAs) were analysed for all constructs. Individual CFAs aim to identify items with a factor loading of less than 0.5 to be dropped, as suggested by Hair et al. (2017). This is to ensure that the item to be removed is proper and is not affected by the strength of the other constructors when the full CFA is in operation. Also, the individual CFA aims to ensure that the model to be built is fit before proceeding to test the whole model (Mulaik \& James, 1995)

Fifteen items out of seventy-six (19.7\%) were omitted, but it is still within an acceptable range. According to Kline 


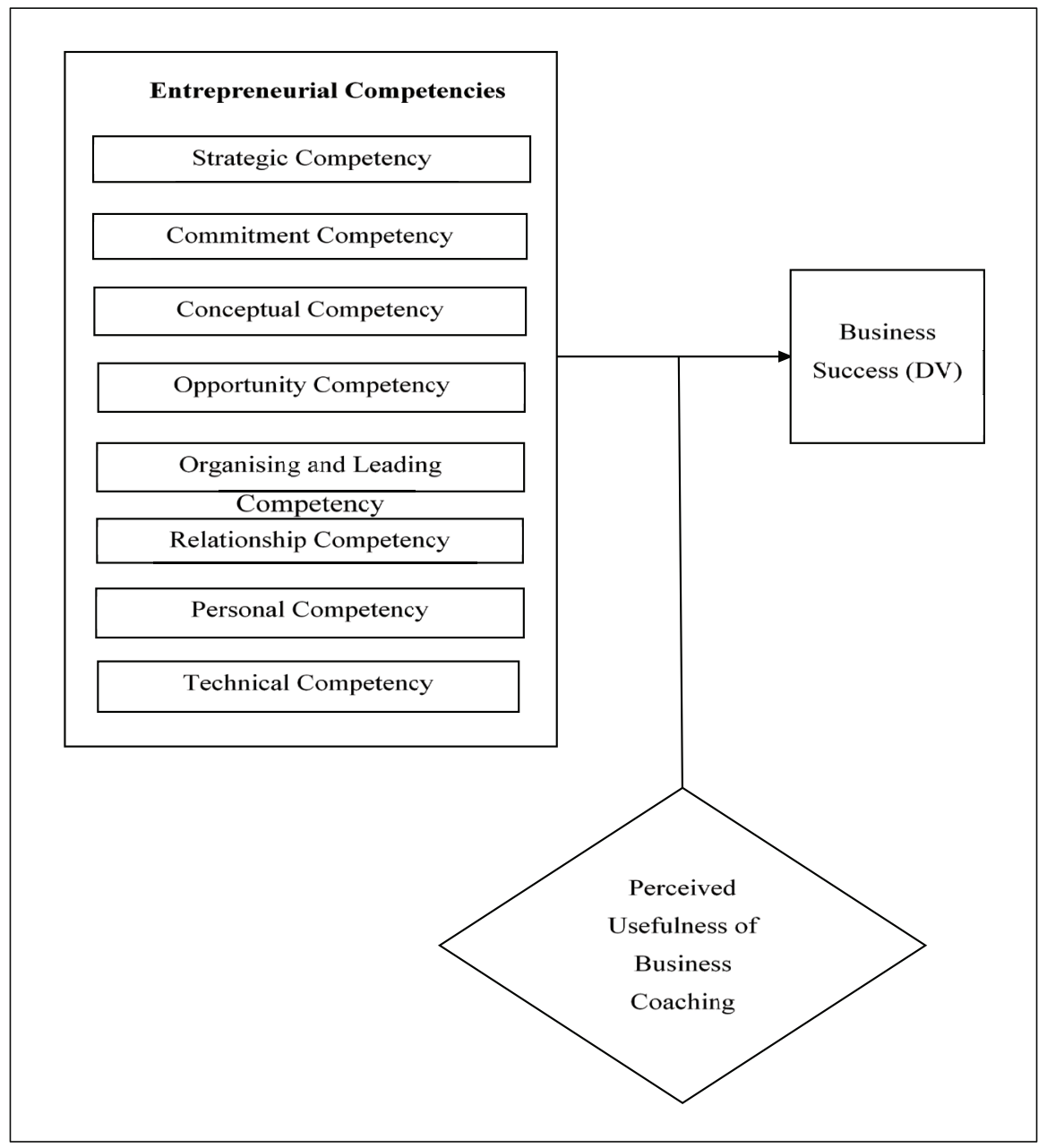

Figure 1: Theoretical Framework

(2010), the removal of items should not be more than $40 \%$ of the total items used. This result indicated that the instrument used to measure the construct is still relevant. Overall, it shows the right level of reliability. The internal consistency approach proposed by Hair et al. (2017) was used to assess the reliability of the measurement scales. A Cronbach's Alpha $(\mathrm{CA} \alpha)$ of 0.70 and above to be considered as an acceptable level of reliability. The instrument's reliability test results showed that all of the CA $\alpha$ values are strong at the range of 0.914 to 0.993 .

\subsection{Full Measurement Model}

After each variable being individually tested, the next CFA test is known as the Full Measurement Model. It incorporates all the variables into one model, and they are tested again to fit the model. Based on the results, the fit model index reports that almost all (except for the p-values) indicators showed that this model is fit and fulfilled the criteria. Although Chi-Square is significant (P-value is less than .05), and it is considered that the model is fit, however, the Chi-Square $\left(\chi^{2}\right) \mathrm{P}$-value statistic is not used as one of the indicators for model fit, as it is often significant when involved the large sample size (Jöreskog \& Sörbom, 1993).

One statistical method that minimizes the impact of sample size on Chi-Square by calculating the Chi-Square $(\chi 2)$ divided by degrees of freedom (df) (Kline, 2010). If the result of this calculation is less than 5 , the model is considered appropriate or fit, and if the consequence depicted that the value is less than 3.0 or near to two, then it is deemed fit (Kline, 2010).

In this study, Chi-Square $\left(\chi^{2}\right)$ results with degrees of freedom (df) were $\chi^{2} / \mathrm{df}=1.690$, while other indicators showed Root Mean Square Error of Approximation (RMSEA) is 0.052, Goodness-of-Fit Index (GFI) is 0.734 , the Increment-Fit-Index (IFI) is 0.922 , Tucker-Lewis coefficient 
Index (TLI) is 0.917, Comparative-Fit-Index (CFI) is 0.922 , and Parsimony Goodness-of-Fit Index (PGFI) is 0.669. So this model can be considered a good model since it meets all the requirements of a fit model except GFI (0.734), which shows not fit model, but does not interfere with the overall model. After the Full Measurement Model has been implemented, validity tests were conducted to ensure that the items could measure the variables. The model is tested based on the Goodness-of-Fit Indices.

\subsection{Measurement Model Evaluation}

The measurement model evaluation of this study was done to determine the reliability and validity of the items. It is made up of internal consistency reliability and construct validity to establish items reliability and construct accuracy (Hair et al., 2014).

\subsubsection{Reliability Analysis}

The internal consistency approach proposed by Hair et al. (2017) was used to assess the reliability of the measurement scales, with a Cronbach's Alpha of 0.70 and above considered an acceptable level of reliability. This study removed fifteen items out of a total of seventysix items used to measure the construct. The removal of these items is due to a Factor Loading less than 0.5, as suggested by Hair et al. (2017). Four items were dropped from organizing and leading competency, three items were omitted from strategic competency and two items each form conceptual competency, relationship competency, and personal competency. Meanwhile, only one item from opportunity competency and technical competency were removed, respectively. However, no items dropped from commitment competency, perceived usefulness of business coaching, and business success.

Although fifteen items were omitted out of seventy-six items or $19.7 \%$ in total, this still within an acceptable range. According to Kline (2010), the removal of items should not be more than $40 \%$ of the total items used. This result means that the instrument used to measure the construct is still relevant. The reliability analysis of each of the study variables showed a good level of reliability. The instrument's reliability test results showed that all of the Cronbach's Alpha values are strong at 0.914 to 0.993 .

\subsubsection{Construct Validity}

Construct Validity is defined as the degree to which a test measures what it claims, or purports, to be measuring (Cronbach \& Meehl, 1955). In modern validity theory, Construct Validity is to confirm that the item used to measure what should be measured (Schotte et al. (1997). To test
Construct Validity, three methods were used, namely, Factor Loading, Composite Reliability (CR), and Average Variance Extracted (AVE). Fifteen items with a low Factor Loading were removed, while the remaining sixty-one items had a higher load factor of 0.5 , indicating that these items can be used.

Two other methods for testing Construct Validity are namely, CR and AVE. Referring to the analysis results, it is found that the $\mathrm{CR}$ values for all constructs are greater than 0.7, namely, business success (0.912), commitment competency (0.894), personal competency (0.931), conceptual competency (0.963), technical competency (0.836), relationship competency (0.883), strategic competency (0.976), opportunity competency (0.882), organizing and leading competency (0.926) and perceived usefulness of business coaching (0.975).

Whereas the AVE values also show that all constructs are greater than 0.5 indicating that all constructs have no problem in terms of Construct Validity, namely, business success (0.775), commitment competency (0.628), personal competency (0.660), conceptual competency (0.766), technical competency $(0.631)$, relationship competency (0.601), strategic competency (0.800), opportunity competency (0.562), organizing and leading competency $(0.586)$ and perceived usefulness of business coaching (0.888).

\subsubsection{Discriminant Validity}

\section{Correlational Method (Nomological Validity)}

Correlational method, also known as Nomological Validity, aims to seek and establish the associations between theoretical constructs (Malhotra, 2019). A correlation matrix was employed to examine the theoretically predicted correlations between the research constructs (i.e., both independent and dependent variables) in the model. In this study, the correlation matrix has presented evidence of the Nomological Validity for the research constructs of both independent and dependent variables, respectively. Most of the constructs were significantly correlated at $\mathrm{p}$-value $<0.01$. Therefore, these constructs were also deployed to examine multicollinearity problems. Since there were no factors with correlation values exceeding 0.90 , it can be concluded that there is no severe problem of multicollinearity (Hair et al., 1998).

\section{Average Variance Extracted (AVE) Method}

According to Hair et al. (2010), Discriminant Validity is the extent to which a construct is truly distinct from other constructs. To evaluate the Discriminant Validity test, the estimated correlations of the construct, which highlight sets of indicators anticipated to assess different constructs should not be too high $(>0.90)$ or low $(<0.10)$ (Hair et al., 1998). The correlations estimated between the related constructs 
in this study showed the highest correlation coefficient value is 0.646 (perceived usefulness of business coaching and business success), which is less than 0.90 . Hence, it is confirmed that the Discriminant Validity is acceptable (Hair et al., 2017).

For this study, Discriminant Validity is also examined through the comparison of the square root of the AVE with the correlation coefficients between the constructs. Byrne (1994) opined that Discriminant Validity is unveiled if the AVE of both constructs' values are higher than the square of the correlation. The analysis revealed that all unobserved variable's square root of 10 constructs was larger than its relationship between every pair of the latent variables. Hence, the Discriminant Validity of all latent variables under study was well recognized and acceptable (Schaupp et al., 2010).

\subsubsection{Normality Test}

Generally, the most basic assumption in any multivariate analysis and, indeed, the last assumption in SEM is that variables are normally distributed (Hair et al., 2017). The arithmetic mean is a good approximation if the skewness value obtained is within \pm 2.0 cut points, as defined by George and Mallery (2003). For kurtosis, cut points less than 7 are acceptable (Byrne, 2010). The skewness and kurtosis values indicated that all items were normally distributed for this study variable.

\subsection{SEM - Direct Model}

The overall direct model confirms the adequacy in representing the sample data. The model fit indices reported that the overall fit indices were accepted for the direct model with $\chi 2 / \mathrm{df}=1.724$, IFI $=0.920$, TLI $=0.914$, CFI
$=0.919$, and PGFI $=0.677$, depicted that the model was fitted. To address the direct hypothesis, which described the hypothesized relationship between the eight latent constructs was developed.

Table 1 shows a summary of the regression weight of the direct relationship between latent construct and dependent variable, namely business success. Based on the outcomes, the results showed that four hypotheses were supported, while another four hypotheses failed to be supported.

\subsection{SEM - Moderation Model}

The moderation through SEM is the comparison between unconstrained models (i.e., variant-group) against the measurement residuals (i.e., invariant-group) models (Hair et al., 2017). To test the hypothesis of moderation, the parameter for the exogenous variable to the endogenous variable was constrained to be equal (measurement residuals); then, the parameter was kept free (unconstraint). Next, the two models were employed subsequently so that it could determine whether or not there is any significant difference in structural parameters between the two groups. Based on the steps in line with the method of Dabholkar and Bagozzi (2002), if there is a significant change in the chi-square between the unconstrained and measurement residuals models, it is conclusive that a moderating effect exists. The difference in the chi-square values between the two models determines whether there is a moderating effect on the relationship between the constructs. The moderating effect can also be observed based on RMSEA, where the smallest of the RMSEA, the better the model (Hair et al., 2017).

A significant improvement in the chi-square value from the unconstrained to the measurement residuals model

Table 1: Summary of Regression Weights

\begin{tabular}{|l|c|c|c|c|c|c|}
\hline Hypothesis & Variables & & Variables & Estimate $(\beta)$ & $\mathbf{P}$ & Result \\
\hline H1 & Business Success & $\leftarrow$ & Strategic Competency & .078 & .187 & Rejected \\
\hline H2 & Business Success & $\leftarrow$ & Commitment Competency & .284 & .001 & Supported \\
\hline H3 & Business Success & $\leftarrow$ & Conceptual Competency & .173 & $* * *$ & Supported \\
\hline H4 & Business Success & $\leftarrow$ & Opportunity Competency & .441 & $* * *$ & Supported \\
\hline H5 & Business Success & $\leftarrow$ & $\begin{array}{c}\text { Organizing and Leading } \\
\text { Competency }\end{array}$ & .120 & .138 & Rejected \\
\hline H6 & Business Success & $\leftarrow$ & Relationship Competency & .214 & .007 & Supported \\
\hline H7 & Business Success & $\leftarrow$ & Personal Competency & .092 & .162 & Rejected \\
\hline H8 & Business Success & $\leftarrow$ & Technical Competency & .128 & .137 & Rejected \\
\hline
\end{tabular}


signifies that the moderator variable has a differential effect on the tested causal path and could be confirmed as a moderator (Hair et al., 2017). It is notable that a significant improvement in the chi-square value is usually established by comparing the calculated value between two models. Consequently, if the calculated change in the chi-square level in unconstrained models is better than the chi-square in measurement residuals models, it is evident that there is a significant change, thus supporting the moderating effects (Hair et al., 2017).

Based on the preceding procedure, the moderating variable, namely, perceived usefulness of business coaching, recorded a significant change of chi-square and degree of freedom compared to the unconstrained models and measurement residuals models. Additionally, the values of other indicators (i.e. RMSEA, GFI, IFI, TLI, CFI, and PGFI) for the unconstrained models are better than those of the measurement residuals models.

Based on Table 2, it is obvious that there was a significant improvement of the chi-square value from the measurement residuals model (5203.415) to the unconstrained model (4744.490). The results also revealed that there was a significant difference. The chi-square for the unconstrained model was smaller than the chi-square of measurement residual with the difference $\chi 2=458.925$ and a significant value less than $.05(\mathrm{p}=0.000)$. Since the difference was significant, this study concluded that there is some form of moderation effect of perceived usefulness of business coaching on the overall model.

In this study, it is crucial to have a close inspection about moderation effect of perceived usefulness of business coaching in the relationship between the eight independent variables (i.e., strategic, commitment, conceptual, opportunity, organizing and leading, relationship, personal, and technical competencies) and business success. To achieve this, the perceived usefulness of business coaching was divided into two groups, namely perceived usefulness of business coaching group 1 (i.e., with a low mean) and perceived usefulness of business coaching group 2 (i.e., with a high mean) as suggested by Hair et al. (2017). According to James and Brett (1984), the samples must be divided into two groups according to the median score of moderation variables (in this case, it is perceived usefulness of business coaching). Hence, by using the descriptive statistics, the moderating variables were divided based on the median split defined in this study. This is in line with the suggestion of Ping (1996), who argues that this method allows each group to have an adequate sample size.

Based on the analysis results demonstrated in Table 3 , the median score for perceived usefulness of business coaching was 6.4 out of 7 points of the scale. This study assumes 1 to 6.4 as the low group (i.e., group 1) of perceived usefulness of business coaching, while 6.41 to 7.00 as the high group of perceived usefulness of business coaching (i.e., group 2).

Table 4 shows a comparative analysis of the path coefficients for groups 1 and 2. Based on Hair et al. (2017), the path is moderated by a moderator if the beta value for group 1 is significant (i.e., $\mathrm{p}<0.05)$, while a beta value for group 2 is non-significant (i.e., $\mathrm{p}>0.05$ ).

Table 2: Summary of Model Fit Indices for Unconstrained and Measurement Residuals Models

\begin{tabular}{|l|c|c|c|c|c|c|c|c|c|}
\hline Models & Chi-Square & df & $\mathbf{X}^{2} / \mathbf{d f}$ & RMSEA & GFI & IFI & TLI & CFI & PGFI \\
\hline Unconstrained & 4744.490 & 2896 & 1.638 & .050 & .636 & .860 & .849 & .858 & .577 \\
\hline $\begin{array}{l}\text { Measurement } \\
\text { residual }\end{array}$ & 5203.415 & 3044 & 1.709 & .052 & .613 & .834 & .832 & .834 & .585 \\
\hline Difference & 458.925 & 148 & & & & & & & \\
\hline
\end{tabular}

Note: $\mathrm{df}=$ Degree of Freedom, GFI = Goodness-of-Fit Index, IFI = Increment Fit Index, TLI = Tucker-Lewis coefficient Index, $\mathrm{CFI}=$ Comparative-Fit-Index, RMSEA = Root Mean Square Error of Approximation, PGFI = Parsimony Goodness-of-Fit Index.

Table 3: Median and Group Distribution for Moderation Variables

\begin{tabular}{|l|c|c|c|}
\hline Moderation Variable & Median & Mean Group 1 & Mean Group 2 \\
\hline Perceived Usefulness of Business Coaching & 6.41 & $1.00-6.40$ & $6.41-7.00$ \\
\hline No. of Respondents & & 134 & 127 \\
\hline
\end{tabular}


Table 4: Comparisons of Path Coefficients for Group 1 and Group 2

\begin{tabular}{|l|c|c|c|c|c|c|}
\hline \multirow{2}{*}{ Hypothesis } & \multirow{2}{*}{ Paths } & \multicolumn{2}{|c|}{$\begin{array}{c}\text { Group 1 } \\
\text { Perceived usefulness of } \\
\text { business coaching }\end{array}$} & \multicolumn{2}{c|}{$\begin{array}{c}\text { Group 2 } \\
\text { Perceived usefulness of } \\
\text { business coaching }\end{array}$} & \multirow{2}{*}{ Indicator } \\
\cline { 3 - 6 } & & Est. $(\boldsymbol{\beta})$ & p-value & Est. ( $\boldsymbol{\beta})$ & p-value & \\
\hline $\mathrm{H} 9$ & $\mathrm{SC} \rightarrow \mathrm{BS}$ & .234 & ${ }^{* *}$ & .041 & .679 & Supported \\
\hline $\mathrm{H} 10$ & $\mathrm{CC} \rightarrow \mathrm{BS}$ & .453 & ${ }^{* * *}$ & -.003 & .974 & Supported \\
\hline $\mathrm{H} 11$ & $\mathrm{Con} \rightarrow \mathrm{BS}$ & .327 & ${ }^{* * *}$ & .165 & .077 & Supported \\
\hline $\mathrm{H} 12$ & $\mathrm{OC} \rightarrow \mathrm{BS}$ & .221 & ${ }^{* *}$ & .389 & ${ }^{* *}$ & Rejected \\
\hline $\mathrm{H} 13$ & $\mathrm{OLC} \rightarrow \mathrm{BS}$ & -.034 & .711 & .026 & .802 & Rejected \\
\hline $\mathrm{H} 14$ & $\mathrm{RC} \rightarrow \mathrm{BS}$ & .250 & ${ }^{* *}$ & .102 & .336 & Supported \\
\hline $\mathrm{H} 15$ & $\mathrm{PC} \rightarrow \mathrm{BS}$ & -.022 & .800 & .253 & ${ }^{* *}$ & Rejected \\
\hline $\mathrm{H} 16$ & $\mathrm{TC} \rightarrow \mathrm{BS}$ & -.101 & .389 & .054 & .631 & Rejected \\
\hline
\end{tabular}

$\mathrm{P}$ (Sig.) $=^{*}<0.05 ;{ }^{* *}<0.01 ;{ }^{* * *}<0.001$

BS = Business Success $;$ CC = Commitment Competency; PC = Personal Competency; Con = Conceptual Competency; TC = Technical Competency; RC = Relationship Competency; SC = Strategic Competency; OC = Opportunity Competency; OLC = Organizing and Leading Competency.

\section{Findings and Discussion}

The main findings of this study indicated that eight out of sixteen hypotheses were validated and supported the conclusions of the previous studies. The domain of entrepreneurial competencies, namely, commitment competency, conceptual competency, opportunity competency, and relationship competency, had a significant influence on the business success of women microentrepreneurs. Hence, these competencies could be considered to be predictors of their business success.

This current study also suggested that the perceived usefulness of business coaching indeed plays a moderating role for the relationships of strategic competency, commitment competency, conceptual competency, and relationship competency towards the women microentrepreneurs business success. Therefore, it can be concluded that domains of entrepreneurial competencies of women micro-entrepreneurs, including strategic competency, commitment competency, conceptual competency, opportunity competency, and relationship competency, together with perceived usefulness of business coaching are vital to the business success of women microentrepreneurs in Malaysia. All in all, these entrepreneurial competencies should remain the principal focus of future research in women entrepreneurship.

\section{References}

Ahmad, N. H., Halim, H. A., \& Zainal, S. R. M. (2010). Is entrepreneurial competency the silver bullet for SME success in a developing nation. International Business Management, 4(2), 67-75. https://doi.org/10.3923/ibm.2010.67.75

Al Mamun, A., Rajennd, A., Muniady, L., Permarupa, P. Y., Zainol, N. R. B., Nawi, N. B. C., \& Malarvizhi, C. A. (2016). Social capital and entrepreneurial competencies: A study among women micro-entrepreneurs in Malaysia. The Journal of Developing Areas, 50(5), 363-370. https://doi.org/10.1353/ jda.2016.0050

Bradley, J. (2009). The technology acceptance model and other user acceptance theories. In: K. Yogesh, B. L. Dwivedi, \& M. D. Williams (Eds.), Handbook of research on contemporary theoretical models in information systems (pp. 277-294). Hershey, PA: IGI Global.

Byrne, B. M. (2010). Structural Equation Modelling with AMOS: Basic concepts, application, and programming (2nd ed.). New York, NY: Routledge Taylor \& Francis Group.

Byrne, B. M. (1994). Structural equation modeling with EQS and EQS/Windows: Basic concepts, applications, and programming. Newcastle upon Tyne, UK: Sage.

Cronbach, L. J., \& Meehl, P. E. (1955). Construct Validity in Psychological Tests. Psychological Bulletin, 52(4), 281-302.

Dabholkar, P. A., \& Bagozzi, R. P. (2002). An attitudinal model of technology-based self-service: Moderating effects of consumer traits and situational factors. Academy of Marketing Science, 30(3), 184-197. https://doi.org/10.1177/0092070302303001

Dobrea, M., \& Maiorescu, I. (2015). Entrepreneurial outcomes and organisational performance through business coaching. Amfiteatru Economic Journal, 17(38), 247-260.

Ellinger, A. D., Ellinger, A. E., \& Keller, S. B. (2003). Supervisory coaching behavior, employee satisfaction, and warehouse 
employee performance: A dyadic perspective in the distribution industry. Human Resource Development Quarterly, 14(4), 435-458. https://doi.org/10.1002/hrdq.1078

Fornell, C., \& Larcker, D. F. (1981). Evaluating structural equation models with unobservable variables and measurement error. Journal of Marketing Research, 48, 39-50. https://doi. org/10.1177/002224378101800312

Hair, J. F., Hult, G. T. M., Ringle, C. M., \& Sarstedt, M. (2017). A Primer on Partial Least Squares Structural Equation Modeling (2nd ed.). Thousand Oaks, CA: Sage Publications.

Hair, Jr., J. F., Black, W. C., Babin, B. J., \& Anderson, R. E. (2010). Multivariate data analysis (7th ed.). Upper Saddle River, NJ: Prentice Hall.

Hair, J. F. J., Anderson, R. E., Tatham, R. L., \& Black, W. C. (1998). Multivariate Data Analysis (5th ed.). Upper Saddle River, NJ: Prentice Hall.

James, L. R., \& Brett, J. M. (1984). Mediators, Moderators, and Tests for Mediation. Journal of Applied Psychology, 69, 307-321. https://doi.org/10.1037/0021-9010.69.2.307

Jöreskog, K. G., \& Sörbom, D. (1993). LISREL 8: Structural equation modeling with the SIMPLIS command language. Lincolnwood, IL: Scientific Software International.

Jung, M. L., \& Berthon, P. (2009). Fulfilling the promise: A model for delivering successful online health care. Journal of Medical Marketing, 9(3), 243-254. https://doi.org/10.1057/ jmm.2009.26

Lazer, N., \& Paul, G. (2015). Entrepreneurial competencies effect on SMEs performance through the mediating effect of psychological contracting of outsourcing. International Journal of Business and Economic Development, 3(2), 23-38.

Lee, W. S., \& Kim, B. Y. (2019). The effects of career orientations on entrepreneurial satisfaction and business sustainability. Journal of Asian Finance, Economics and Business, 6(4), 235-248. https://doi.org/10.13106/jafeb.2019.vol6.no4.235

Kline, R. B. (2010). Principles and practice of structural equation modeling (3rd ed.). New York, NY: Guilford Press.

Malhotra, N. K. (2019). Marketing research: An applied orientation ( $7^{\text {th }}$ ed.). New York, NY: Pearson Education Inc.

Man, T. W., \& Lau, T. (2005). The context of entrepreneurship in Hong Kong: An investigation through the patterns of entrepreneurial competencies in contrasting industrial environments. Journal of Small Business and Enterprise Development, 12(4), 464-481. https://doi. org/10.1108/14626000510628162

Man, T. W., \& Lau, T. (2000). Entrepreneurial competencies of SME owner/managers in the Hong Kong services sector: A qualitative analysis. Journal of Enterprising Culture, 8(3), 235254. https://doi.org/10.1142/S0218495800000139

Mitchelmore, S., \& Rowley, J. (2013). Entrepreneurial competencies of women entrepreneurs pursuing business growth. Journal of Small Business and Enterprise Development, 20(1), 125-142. https://doi.org/10.1108/14626001311298448
Mitchelmore, S., \& Rowley, J. (2010). Entrepreneurial competencies: A literature review and development agenda. International Journal of Entrepreneurial Behavior \& Research, 16(2), 92-111. https://doi.org/10.1108/13552551011026995

Mole, V., Dawson, S., Winstanley, D., \& Sherval, J. (1993). Researching managerial competencies. Paper presentation at the British Academy of Management Annual Conference. Milton Keynes.

Mulaik S. A., \& James, L. R. (1995). Objectivity and reasoning in science and structural equation modeling. In: R. H. Hoyle (Ed.), Structural Equation Modeling: Concepts, issue and applications (pp. 118-137). London, UK: Sage Publications.

Mustapa, N. S., Noor, K. M., \& Mutalib, M. A. (2018). Why can't we have both? A discussion on work-life balance and women career advancement in Malaysia. Journal of Asian Finance, Economics and Business, 5(3), 103-112. https://doi. org/10.13106/jafeb.2018.vol5.no3.103

Ng, H. S., \& Kee, D. M. H. (2013). Effect of entrepreneurial competencies on firm performance under the influence of organisational culture. Life Science Journal, 10(4), 2459-2466.

Omar, N. A., Nazri, M. A., \& Wel, C. A. C. (2014). Entrepreneurial training of low-income women micro enterprises in the service sector in Malaysia: Understanding the problems and challenges. Journal of Social and Development Sciences, 5(4), 245. https:// doi.org/10.22610/jsds.v5i4.824.g824

Onyemah, V. (2009). The effects of coaching on salespeople's attitudes and behaviors: A contingency approach. European Journal of Marketing, 43(7/8), 938-960. https://doi. org/10.1108/03090560910961461

Othman, N., \& Ishak, S. B. (2009). Attitude towards choosing a career in entrepreneurship amongst graduates. European Journal of Social Sciences, 10(3), 419-434.

Ping, R. (1996). Latent variable interaction and quadratic effect estimation: A two-step technique using structural equation analysis. The Psychological Bulletin, 119, 166-175. https://doi. org/10.1037/0033-2909.119.1.166

Satpayeva, Z. T., Kireyeva, A. A., Kenzhegulova, G., \& Yermekbayeva, D. (2020). Gender Equality and Women Business of Framework 5Ms in Kazakhstan: Analysis and Basic Directions. Journal of Asian Finance, Economics and Business, 7(3), 253-263. https://doi.org/10.13106/jafeb.2020. vol7.no3.253

Schaupp, L. C., Carter, L., \& McBride, M. E. (2010). E-file adoption: A study of US taxpayers intentions. Computer in Human Behavior, 26(4), 636-644. https://doi.org/10.1109/ HICSS.2009.171

Schotte, C. K. W., Maes, M., Cluydts, R., De Doncker, D., \& Cosyns, P. (1997). Construct validity of the Beck Depression Inventory in a depressive population. Journal of Affective Disorders. 46(2), 115-125. https://doi.org/10.1016/S01650327(97)00094-3

Tehseen, S., \& Ramayah, T. (2015). Entrepreneurial competencies and SMEs business success: The contingent role of external 
integration. Mediterranean Journal of Social Sciences, 6(1), 50-61. https://doi.org/10.5901/mjss.2015.v6n1p50

Walker-Fraser, A. (2011). Coaching and the link to organisational performance: an HR perspective on how to demonstrate return on investment. Development and Learning in
Organisations: An International Journal, 25(4), 8-10. https:// doi.org/10.1108/14777281111147035

Zainol, N. R., Al Mamun, A., Hassan, H., \& Muniady, R. (2017). Examining the effectiveness of micro-enterprise development programs in Malaysia. Journal of International Studies, 10(2), 292-308. https://doi.org/10.14254/2071-8330.2017/10-2/20 